\title{
Buzzing around the intellect
}

\section{R. S. Woolhouse}

Leibniz: A Biography. By E. J. Aiton. Adam Hilger: 1985. Pp. 370. £29.50, \$55.

To Ramazzini, the father of industrial medicine, Gottfried Leibniz (1646-1716) was unsurpassed in the range of his intellectual accomplishments; to another contemporary, the philosopher Christian Thomasius, he was a living library. But it was his close friend, Sophie, Electress of Hanover, who best caught his style in comparing him to a bee, sucking honey everywhere he found it. Besides suggesting personal charm, the remark indicates the unremitting industry and persistence, the openness to stimulation from any quarter, and the imaginative eye for the constructive development of a chance idea, which characterized the life of this universalgenie. Like one of his metaphysical monads, he was a living mirror of the whole world. Active in diplomacy and politics, original in philosophy and mathematics, technologically inventive, he took a constructive interest in whatever came his way -- be it law, geology, chemistry, Chinese writing, economics, industrial management, genealogy, public health or theology. Quite apart from his

\section{NUGLEAR POWER} AND ITS

\section{ENVIRONMENTAL} EFFECTS

\section{For the Layman, Nuclear Technician, Manager}

Places the effects of possible nuclear radiation in perspec ve. Meets the need for a better understanding of radiation and its consequences especially after the TMI accident.

All vital aspects of nuclear power generation are considered, from fundamental principles to plant licensing, from uranium mining to disposal of waste. The safe operation of nuclear power plants, to prevent the escape of dangerous amounts of materials in case of an accident, is fully covered.

By Samuel Glasstone Walter $\mathrm{H}$. Jordan

American Nuclear Society

555 No. Kensington Ave.

La Grange Park, IL 60525 USA

The source for the latest knowledge in Nuclear purely intellectual and diplomatic activities, at one moment he might be at work on the construction of a calculating machine, chronometer or drainage pump, at another composing a poem to commemorate a birth or death, or designing a medal as a New Year present.

According to Bertrand Russell, Leibniz deliberately preferred a courtly life and the company of the socially great to an academic career. He has encouraged us to think of a man flawed, even held back, by somewhat worldly interests. It is true that Leibniz, having refused a professorship at the age of 21 , was not long in acquiring the first of his distinguished noble patrons, Baron Johann von Boineburg. But it was his intellectual plans he thought could not come to fruition in a university, not his social aspirations. He made plain to his future employer, Duke Johann Friedrich of Hanover, that what he sought was time and financial support for his scientific and cultural projects. It is absolutely clear that he would have preferred to remain in the intellectual hot-house of Paris, with a paid appointment from the Academy of Sciences, than go to Hanover.

Russell has also encouraged the picture of Leibniz as a man whose talents were wasted and dissipated by being spread too thinly. But what emerges from E. J. Aiton's absorbingly extensive and detailed biography is not only the scale of some of Leibniz's ideas but also the farreaching practical imagination and persistence with which he sought to carry them out. From early on in his schooldays, and throughout much of his life, he worked on the idea of a universal characteristic. The initial conception was of an alphabet of human thought, a universal language that would speak to the understanding rather than to the eye. By its means even such subjects such as metaphysics and ethics would be amenable to the same sort of proof as algebra and geometry. As a basis for demonstration and discovery of all truth the calculus would presuppose an encyclopaedia of all existing knowledge. As Leibniz began to see, the compilation of such an encyclopaedia, not to say the development of the calculus itself, required scholarly collaboration on a large scale. With this in mind he envisaged an Academy to carry it out and sought the help of Duke Friedrich, suggesting the use of the increased profits from the Harz mines drainage scheme he worked on. Nor was this the only scheme with which Leibniz persisted. Another was a plan for the reunification of the Churches, on which he worked both by way of political and diplomatic lobbying and by way of establishing its theoretical theological foundations. A third was the vast undertaking of the history of the House of Brunswick which was commissioned by Duke Ernst August of Hanover.

Even given that he seems to have lived only for work, it is astonishing that despite all of these endeavours, and despite the diplomatic and administrative duties that came his way from his employers, Leibniz could have had time for the development of the ideas for which he is more famous. He seems to have had the happy knack of making the most of an occasion or of putting to good use any spare moment. Whether on board a boat waiting for the wind to change, or spending the night in an inn on some business journey, he would compose a mathematical paper or write one of his philosophical gems.

Aiton's biography, the first major one in English, tells of all Leibniz's multi-

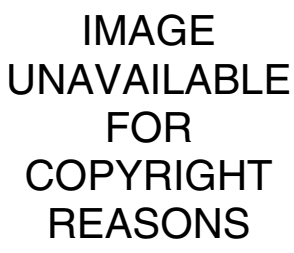

Leibniz - "Active in diplomacy and politics. original in philosophy and mathematics. technologically inventive

farious activities. Also it very usefully explains and summarizes his ideas as expressed in his published and unpublished papers and correspondence. Those wanting a skilfully clear and concise account of anything from Leibniz's development of the differential calculus, through his attacks on Cartesian physics, to the metaphysics of substance and the preestablished harmony will find it here. They will also find much of interest from the point of view of intellectual history in general: the importance of such as Henry Oldenburg, Secretary of the Royal Society, as a clearing-house for ideas; the publication of mathematical results by formal registration and informal circulation; the foundation of scientific societies in the seventeenth century; and the increasing institutionalization and internationalization of science.

There is, however, not much of an explicit account of Leibniz the person. Aiton gives the facts and describes the ideas pertaining to the life of this great man. But he does not attempt any comment on or reconstruction of the personality whose life it was. We learn as a fact that Leibniz considered marriage on two occasions. We learn as facts of the evidently close friendships he had with the Electress Sophie and Queen Sophie Charlotte, and of his illness and depression on the death of the latter. But as to what should be made of them Aiton does not attempt to say.

R.S. Woolhouse is Reader in the Department of Philosophy, University of York, Heslington, York YOI SDD, UK. 